\title{
FENOMENA MELEK POLITIK (POLITICAL LITERACY) MASYARAKAT KOTA AMUNTAI KABUPATEN HULU SUNGAI UTARA
}

\author{
Akhmad Riduan, Budi Lesmana, Nasripani, Reno Affrian \\ Sekolah Tinggi Ilmu Administrasi (STIA) Amuntai \\ Email: renoaffrian@yahoo.com
}

\begin{abstract}
In Amuntai City, Hulu Sungai Utara district, political knowledge citizens are generally relatively low where political terms not understood as it should be in addition to confusion relevance between elections and regional development. Political participation of citizens in general is still low, especially those who work in the informal sector and tend to avoid involvement in practical political activity. Although they participated in the elections, but they just do not care about the output of the election itself. Furthermore, the political interest of citizens were generally quite low because most of them assess prejudice against political activity although no doubt some of those who assess positively to the political world. To increase the political understanding of citizens in Amuntai City, suggested to the election organizers in Hulu Sungai Utara district, especially the Election Commission and the Election Supervisory Committee to conduct an intense political socialization to the community, especially in rural areas. Political socialization should be cooperating with the participation of local governments, organizations of society and universities in the area. Political parties in the region should also undertake political socialization as the embodiment of one of the functions of political parties, especially in the areas that became the basis of a mass political party concerned with promoting political ethics that typically become one of the political ideology of political parties.
\end{abstract}

Keywords: election, political literacy, political

\section{PENDAHULUAN}

Sebagai upaya untuk mewujudkan kemakmuran rakyat, maka salah satu sendi pokok pembangunan berkaitan dengan kehidupan politik berbangsa dan bernegara dalam bingkai negara kesatuan (unitarian). Konsekuensi dari pembangunan bidang politik menghadirkan suksesi kepemimpinan secara langsung yang mengisyaratkan keterlibatan segenap warga negara dalam setiap tahapan pemilihan umum secara demokratis, baik pemilihan presiden/wakilpresiden, pemilihan anggota legislatif (DPR/DPRD), pemilihan kepala daerah (gubernur/wakil gubernur, bupati/walikota dan wakil bupati/wakil walikota) hingga di tingkat terkecil pemilihan kepala desa.

Melihat perkembangan politik di tanah air pasca reformasi yang menguras banyak pengorbanan moril dan materiil dan juga menyisakan nestapa politik, banyak pihak berpandangan bahwa sistem demokrasi yang dianut di Indonesia belumlah berhasil diaplikasikan dalam ranah kultural walaupun struktur demokrasi telah dibangun dengan baik dimana institusi-institusi politik yang ada menguatkan kesan Indonesia sebagai salah satu negara demokrasi di dunia.

Pengalaman terdahulu, masyarakat sebagai calon pemilih disuguhi berbagai atraksi politik para kontestan yang secara simbolik pada umumnya mentahbiskan diri sebagai sosok panutan, religius, dan penyambung lidah masyarakat. Di balik itu, masyarakat Indonesia yang pada umumnya awam politik dan bekerja di sektor informal dengan skala pendidikan menengah ke bawah, suara mereka justru merupakan ladang khayalan para politikus sehingga simbol-simbol politik yang dibalut 
legitnya strategi komunikasi politik oleh mesinmesin politik para kontestan dan bahkan terkadang terkesan narsis berpotensi melemahkan daya nalar politik masyarakat terutama dikalangan grass root.

Secara nasional partisipasi pemilih sejak pemilu 1999 sampai dengan pemilu 2014 bergerak fluktuatif. Pada pemilu legislatif, penurunan partisipasi pemilih sekitar 10 persen konsisten terjadi sampai pada Pemilu 2009. Sementara pada pemilu 2014, angka partisipasinya naik sebesar 5\%. Pada kasus pilpres, tercatat dalam pemilu 2014 pertama kalinya dalam sejarah angka partisipasinya lebih rendah dibandingkan pemilu legislatif (Kariada, 2015).

Pada Kabupaten Hulu Sungai Utara sendiri, pemilihan umum bupati/wakil bupati tahun 2012 diketahui dari 163.655 pemilih hanya sekitar 111.743 atau $68 \%$ pemilih yang datang ke TPS memberikan hak suaranya. Jumlah ini sudah merupakan akumulasi dari suara sah sebesar 105.595 dan suara tidak sah sebesar 6.148. Bandingkan misalnya dengan pemilihan anggota DPD tahun 2014 diempat daerah pemilihan dimana pemilih yang memberikan hak suaranya sebesar 127.570 terdiri atas suara sah 97.421 dan suara tidak sah sebanyak 30.149. Tidak jauh berbeda dengan pemilihan legislatif ditingkat DPR dimana diperoleh jumlah suara pemilih hadir ke TPS sebesar 108.489, ditingkat DPRD Propinsi Kalimantan Selatan jumlah suara pemilih yang memberikan hak suara sebanyak 108.826, dan ditingkat DPRD Kabupaten Hulu Sungai Utara sejumlah 120.805 suara pemilih (Data KPUD HSU Tahun 2012 dan 2014).

Bercermin pada penyelenggaraan pemilihan umum beberapa tahun terakhir nampaknya kualitas pemilihan umum di Indonesia pada umumnya dan di Kabupaten Hulu Sungai Utara khususnya masih jauh dari harapan, terutama dalam hal penentuan pilihanpilihan secara rasional dari para pemilih yang belum terpenuhi (pragmatisme politik) dimana political literacy atau melek politik merupakan salah satu faktor yang berperan besar didalamnya.

\section{TINJAUAN PUSTAKA}

\section{Pemilihan Umum}

Pemilihan Umum (Pemilu) adalah merupakan suatu istilah yang tidak asing bagi masyarakat di negara-negara demokrasi. Pemilu yang diadakan dalam kurun waktu tertentu, baik melewat demokrasi langsung maupun demokrasi perwakilan diyakini mampu mencerminkan makna filosofis dari sistem demokrasi yakni pemerintahan dari rakyat, oleh rakyat, dan untuk rakyat. Menurut Liddle (Pito, 2006), dalam sistem pemerintahan demokrasi pemilu sering dianggap sebagai penghubung antara prinsip kedaulatan rakyat dan praktek pemerintahan oleh sejumlah elit politik. Setiap warga negara yang telah dianggap dewasa dan memenuhi persyaratan menurut Undang-Undang, dapat memilih wakil-wakil mereka di parlemen, termasuk para pemimpin pemerintahan. Kepastian bahwa hasil pemilihan itu mencerminkan kehendak rakyat diberikan oleh seperangkat jaminan yang tercantum dalam peraturan perundang-undangan yang berkaitan dengan pemilu.

Menurut Undang-Undang Republik Indonesia Nomor 8 Tahun 2012 tentang Pemilihan Umum Anggota Dewan Perwakilan Rakyat, Dewan Perwakilan Daerah, dan Dewan Perwakilan Rakyat Daerah, Pemilihan Umum adalah sarana pelaksanaan kedaulatan rakyat yang dilaksanakan secara langsung, umum, bebas, rahasia, jujur dan adil dalam Negara Kesatuan Republik Indonesia berdasarkan Pancasila dan Undang-undang Dasar Negara Republik Indonesia tahun 1945. Sementara itu, Nohlen (Pito, 2006) berpandangan bahwa Pemilu merupakan "satu-satunya metode demokratik" untuk memilih wakil rakyat.

Dari beberapa pengertian diatas, dapat diambil kesimpulan bahwa pemilu sesungguhnya adalah media politik bagi rakyat untuk menyampaikan pilihan-pilihan politiknya secara demokratis sehingga dari suatu pemilu dihasilkan sejumlah elit politik yang dianggap merupakan representasi dari suara rakyat.

Pemilih dalam pemilu disebut juga sebagai konstituen, dimana para peserta atau kontestan Pemilu menawarkan janji-janji dan program-programnya pada masa kampanye 
kepada para konstituen. Kampanye sendiri dilakukan pada waktu yang telah ditentukan menjelang hari pemungutan suara. Setelah pemungutan suara dilakukan, maka proses penghitungan dimulai. Pemenangan Pemilu ditentukan oleh aturan main atau sistem penentuan pemenang yang sebelumnya telah ditetapkan dan disetujui oleh para peserta dan disosialisasikan kepada para pemilih. Dikarenakan hal tersebut, maka pemilu berpeluang untuk terjadi penyimpangan atau kecurangan. Dalam konteks inilah Le Duc (Pito, 2006) menyatakan pemilu sebagai sebuah lembaga politik yang mendorong (leads) dan mencerminkan banyak kecenderungan sosial, politik, dan ekonomi.

Proses pemilihan umum merupakan bagian dari demokrasi karena pemilu memberikan dukungan dan legitimasi politik terhadap rezim baru yang terpilih. Oleh karenanya, hampir semua sarjana politik beberapa diantaranya Dahl (1985), Carter dan Herz (1982), Mayo (1982), Ranney (1990), dan Sundhaussen (1992) sepakat bahwa pemilu merupakan satu kriteria penting untuk mengukur kadar demokrasi suatu sistem politik (Suryadi, 2008). Bahkan lebih jauh Sanit (Pito, 2006) menandaskan empat fungsi yang diemban oleh suatu pemilu yakni legitimasi politik, terciptanya perwakilan politik, sirkulasi elite politik, dan pendidikan politik.

\section{Tujuan Pemilihan Umum}

Menurut Sanit (Pito, 2006), pemilu yang diselenggarakan dalam kurun waktu tertentu bertujuan sebagai berikut :

a. Melaksanakan kedaulatan rakyat yang menjamin kepentingan semua golongan.

b. Menentukan wakil rakyat yang sekaligus harus melayani penguasa dan rakyat secara seimbang.

c. Membentuk pemerintahan perwakilan lewat OPP pemenang (tunggal atau oposisi).

d. Pergantian atau pengukuran elite penguasa.

e. Pendidikan politik bagi rakyat melalui partisipasi dalam pemilu.

Sementara itu, Surbakti (1999) menjelaskan beberapa tujuan dari pemilu yakni : a. Sebagai mekanisme untuk menyeleksi para pemimpin pemerintahan dan alternatif kebijakan umum.

b. Pemilu juga dapat dikatakan sebagai mekanisme memindahkan konflik kepentingan dari masyarakat kepada badanbadan perwakilan rakyat melalui wakil-wakil rakyat yang terpilih atau melalui partai-partai yang memenangkan kursi sehingga integrasi masyarakat tetap terjamin.

c. Pemilu merupakan sarana memobilisasikan dan/atau menggalang dukungan rakyat terhadap negara dan pemerintahan dengan jalan ikut serta dalam proses politik.

\section{Azas Pemilihan Umum}

Pemilu yang diselenggarakan pemerintah seyogyanya memenuhi beberapa azas tertentu yang apabila dijabarkan Pito (2006) terbagi atas:

a. Berkala (teratur)

Hal ini berarti pemilu dilaksanakan secara teratur sesuai dengan konstitusi dan ketentuan yang diatur oleh negara bersangkutan.

b. Langsung

Dalam hal ini pemilih mempunyai hak untuk secara langsung memberikan suaranya sesuai dengan kehendak hati nuraninya, tanpa perantara dalam memilih wakil-wakil yang akan duduk di lembaga perwakilan rakyat dan di pemerintahan.

c. Umum

Maksudnya pemilu diikuti oleh setiap orang yang sudah memenuhi syarat.

d. Bebas

Dalam memberikan suara, si pemilih tidak ada tekanan dari pihak manapun yang memungkinkan dia memberikan suara tidak sesuai dengan hati nuraninya. Dia benarbenar bebas dalam menentukan pilihannya.

e. Rahasia

Artinya kerahasiaan pemberi suara atas calon atau organisasi/partai peserta pemilu yang dipilihnya tidak akan diketahui oleh siapapun, termasuk panitia pemungutan suara sehingga pemilih bebas dari ketakutan atau ancaman dari pihak manapun dalam memberikan suaranya dan setelah dia memberi suaranya.

f. Jujur 
Maksudnya adalah tidak boleh terjadi kecurangan-kecurangan dalam pemilu tersebut, baik oleh penyelenggara atau oleh organisasi partai peserta pemilu.

g. Adil

Dalam penyelenggaraan pemilu setiap pemilu dan partai politik peserta pemilu mendapat perlakuan yang sama serta bebas dari kecurangan pihak manapun.

\section{Sosialisasi Politik Dan Melek Politik}

Penyelenggaraan pemilu merupakan hajatan kolektif masyarakat dalam rangka memilih para pemimpin politik dilembaga parlemen dan pemerintahan diberbagai tingkatan. Penyelenggaraan suatu pemilu dapat disebut demokratis oleh Hadenius (Pito, 2006) bila merujuk pada tiga kiteria sehingga dapat dikatakan pemilu tersebut memiliki makna. Tiga kriteria tersebut adalah keterbukaan, ketepatan dana, dan keefektifan pemilu.

Melihat pendapat diatas, urgensi terhadap sosialisasi politik yang efektif terhadap warga negara merupakan suatu keharusan, baik yang dilakukan secara formal oleh negara melalui serangkaian perangkatnya maupun secara informal oleh pihak-pihak di luar negara seperti partai politik dan organisasi massa lainnya.

Dawson dan Prewitt (Fathurrahman, 2004) menjelaskan, sosialisasi politik merupakan proses pembentukan sikap dan orientasi politik para anggota masyarakat.

Surbakti (1999) menyatakan hal yang sama bahwa sosialisasi politik tidak lain adalah proses pembentukan sikap dan orientasi politik para anggota masyarakat. Melalui proses sosialisasi politik inilah para warga masyarakat memperoleh sikap dan orientasi terhadap kehidupan politik yang berlangsung dalam masyarakat. Dari segi metode penyampaian pesan, sosialisasi politik terbagi dua yakni pendidikan politik dan indoktrinasi politik. Pertama, pendidikan politik merupakan proses dialogik di antara pemberi dan penerima pesan. Melalui proses ini para anggota masyarakat mengenal dan mempelajari nilai-nilai, normanorma, dan simbol-simbol politik negaranya dari berbagai pihak dalam sistem politik seperti sekolah, pemerintah, dan partai politik. Pendidikan politik dianggap sebagai proses dialog antara pendidik seperti sekolah, pemerintah, partai politik, dan peserta didik dalam rangka pemahaman, penghayatan, dan pengamalan nilai, norma, dan simbol politik yang dianggap ideal dan baik melalui berbagai bentuk kegiatan tertentu. Kedua, indoktrinasi politik yang berarti proses sepihak ketika penguasa memobilisasi dan memanipulasi warga masyarakat untuk menerima nilai, norma, dan simbol yang dianggap pihak berkuasa sebagai ideal dan baik. Melalui berbagai forum pengarahan yang penuh paksaan psikologis dan latihan yang penuh disiplin, partai politik dalam sistem politik totaliter melaksanakan fungsi indoktrinasi politik.

Tak jauh berbeda, Almond dan Powell (Fathurrahman, 2004) mengungkapkan bahwa istilah sosialisasi mengacu pada cara-cara bagaimana anak-anak diperkenalkan pada nilainilai yang ada dalam masyarakat dimana ia tinggal. Sosialisasi politik adalah bagian dari proses ini yang membentuk sikap politik.

Dari beberapa pengertian diatas, dapat dijelaskan bahwa sosialisasi politik merupakan suatu proses yang berlangsung seumur hidup dimana dalam proses ini para warga masyarakat memperoleh sikap dan orientasinya terhadap kehidupan politik yang berlangsung dalam masyarakat. Sosialisasi politik dilakukan oleh berbagai pihak baik secara formal maupun informal.

Dalam kaitannya dengan sosialisasi politik, sering diperbincangkan istilah melek politik (political literacy) dimana Crick (2015) melihat melek politik menyangkut pemahaman tentang konsep-konsep, even-even, serta hakhak politik yang berlangsung di dalam kehidupan sehari-hari.

Dengan kata lain, melek politik dalam konteks pemilu dipahami sebagai kemampuan masyarakat untuk mendefinisikan kebutuhan mereka akan substansi politik terutama perihal pemilu. Dari sini dapat dipahami bahwa melek politik dikur dari seberapa peka dan pedulinya warga masyarakat terhadap peristiwa-peristiwa dan bahasa-bahasa politik dilingkungan sekitarnya.

Studi terhadap melek politik sendiri berkaitan erat dengan kualitas penyelenggaraan pemilu disuatu negara yang menghasilkan 
sejumlah aktor politik diberbagai tingkatan diparlemen dan di pemerintahan. Sejatinya melek politik tidak hanya mengupayakan pemahaman warga masyarakat namun lebih dari itu menimbulkan dorongan untuk terlibat aktif di ruang publik. Oleh sebab itulah, seperti dikutip Bochel (2015), untuk membangun relevansi politik dalam bingkai kewarganegaraan dibutuhkan tiga hal pokok yakni pengetahuan politik, partisipasi politik, dan minat politik.

\section{METODE PENELITIAN}

Pendekatan kualitatif dipilih dalam upaya menganalisa permasalahan berkenaan dengan kondisi melek politik (political literacy) warga masyarakat Kota Amuntai Kabupaten Hulu Sungai Utara.

Analisa data menggunakan teknik Miles dan Huberman. Teknik yang digunakan sebagaimana dimaksud adalah : 1). Pengumpulan Data (Data Collection), 2). Reduksi Data (Data Reduction), 3). Penyajian Data (Data Display), 4). Kesimpulan: Penggambaran/ Verifikasi (Conclusion: Drawing/Verification)

\section{HASIL DAN PEMBAHASAN}

\section{A. Pengetahuan Politik}

Pengetahuan politik menunjukkan salah satu hal yang dapat menunjukkan tingkat pemahaman warga masyarakat Kota Amuntai Kabupaten Hulu Sungai Utara terutama dalam konteks Pemilu yang diselenggarakan setiap lima tahun sekali, baik Pemilu Legislatif maupun Eksekutif. Untuk itu perlu pemaknaan yang benar akan istilah politik.

\section{Makna Politik}

Secara literal, istilah politik bukanlah istilah yang baru dalam sejarah peradaban manusia karena ia merupakan salah satu naluri yang hidup dalam setiap jenis makhluk hidup. Politik dalam konteks suatu negara tidak bisa dilepaskan dalam koridor negara kesejahteraan (welfare state). Politik memberi warna terhadap tumbuhkembangnya suatu negara yang berimbas pada tingkat kesejahteraan masyarakat dan pada awalnya diwujudkan dari kebijakan elit politik.
Istilah politik bagi warga masyarakat tentu menimbulkan pemahaman yang beranekaragam tergantung dari perspektif atau sudut pandangnya masing-masing. Di beberapa tempat strategis menjelang Pemilu biasanya ditempatkan baliho besar dalam upaya mengenalkan warga masyarakat tentang apa itu politik terutama terkait pemilu walaupun memang tidak besar pengaruhnya karena baliho bersifat komunikasi sepihak. Tak heran muncul makna politik yang buruk muncul di tengah warga masyarakat.

Dari sejumlah informasi diatas dapat diketahui bahwa sebagian besar warga masyarakat memberikan makna terhadap istilah politik diluar makna politik yang sesungguhnya bernilai filosofis itu. Dengan kata lain, sebagian besar dari mereka cenderung tak sepenuhnya memahami makna yang terkandung dalam istilah politik walaupun pada kenyataannya istilah tersebut sangat familiar diruang dengar warga masyarakat.

\section{Pemilihan Umum}

Ketika istilah politik diketengahkan, salah satu aspek yang seringkali muncul adalah menyangkut pemilihan umum terutama di negara-negara yang menganut demokrasi seperti halnya di Indonesia, baik demokrasi yang bersifat langsung maupun perwakilan. Untuk kepentingan penyelenggaraan pemilu, KPU Kabupaten Hulu Sungai Utara, Panwaslu Kabupaten Hulu Sungai Utara, dan pihak-pihak terkait lain biasanya menyampaikan perihal pemilu melalui berbagai media, baik baliho, poster, hingga melalui siaran TV pemerintah Kabupaten Hulu Sungai Utara.

Warga masyarakat Kota Amuntai memahami Pemilu sebagai sebuah perwujudan demokratisasi yang mendasar dimana setiap individu memiliki kebebasan politik untuk menentukan orientasi politik disuatu negara. Hal ini sejalan dengan pandangan Surbakti (1999) bahwa salah satu tujuan dari pemilu adalah sebagai mekanisme untuk menyeleksi para pemimpin pemerintahan dan alternatif kebijakan umum selain juga bersesuaian dengan pendapat Sanit (Pito,2006) dimana diantaranya pemilu bertujuan untuk melaksanakan kedaulatan rakyat yang menjamin kepentingan semua golongan 
selain sebagai sarana untuk mewujudkan kesejahteraan rakyat dalam mana aspirasi masyarakat diamanahkan kepada para elit politik terpilih dan sarana pendidikan politik bagi rakyat melalui partisipasi dalam pemilu.

\section{Pemilu Dan Pembangunan Daerah}

Dalam kaitannya dengan pembangunan daerah, pemilu sesungguhnya merupakan entry point bagi setiap kontestan pemilu untuk mengabdikan dirinya bagi pembangunan bangsa dan negara termasuk daerah di era desentralistik sekarang ini bilamana mereka terpilih. Dapat dipahami bila hasil pemilu akan sangat menentukan terhadap proses pembangunan yang berarti pula menentukan tingkat kesejahteraan masyarakat. Harapan yang begitu besar diamanahkan kepada setiap calon terpilih baik dilegislatif maupun eksekutif, dipusat/daerah semuanya tentu disamping membawa implikasi politis, ekonomi, dan lainnya tentu juga membawa implikasi moral sebab dalam pandangan demokrasi, ada etika politik yang mesti ditunaikan sebagai bentuk akuntabilitas.

Di Kota Amuntai, sebagian besar warga masyarakat terutama kalangan menengah ke bawah tidak mengerti urgensi pemilu bagi pembangunan daerah/bangsa yang pada gilirannya turut membawa dampak pada kesejahteraan mereka sendiri. Warga masyarakat cenderung mengikuti pemilu sebagai suatu keharusan namun tidak memahami apa yang menjadi orientasi mendasar suatu pemilu.

Melihat realitas yang ada mengacu pemahaman masyarakat Kota Amuntai menyangkut makna politik, pemilu, dan juga relevansinya terhadap pembangunan daerah, dapat dipahami pengetahuan politik warga masyarakat Kabupaten Hulu Sungai Utara umumnya masih rendah terutama mereka yang berpendidikan menengah ke bawah. Hal ini terlihat dari Secara prinsipil hal ini bertentangan dengan maksud pengetahuan politik yang dikutip Bochel (2015) dalam upaya pendidikan kewarganegaraan bagi peningkatan angka melek politik. Sejalan dengan itu, Crick (2015) justru lebih melihat melek politik menyangkut pemahaman tentang konsep-konsep, even-even, serta hak-hak politik yang berlangsung di dalam kehidupan sehari-hari.

\section{B. Partisipasi Politik}

Perwujudan dari kedaulatan politik warga masyarakat biasanya mudah dilihat dari sejauh mana partisipasi mereka dalam berbagai aktivitas politik, baik yang bersifat langsung maupun tak langsung. Partisipasi politik sendiri bisa dilakukan dalam berbagai bentuk seperti menjadi pengurus ormas/orsospol, kelompok kepentingan/penekan turut terlibat dalam penggalangan opini publik, dan lain sebagainya.

\section{Keterlibatan Warga Dalam Kelembagaan Suatu Ormas/Parpol}

Kelembagaan ormas/parpol adalah sarana kelembagaan bagi aktualisasi politik warga masyarakat dalam iklim demokrasi. Sebagai bagian dari infrastruktur politik, maka parpol, kelompok kepentingan/penekan, dan opini publik adalah suatu instrumen bagi warga masyarakat untuk menyuarakan aspirasinya.

Partisipasi politik yang dapat digalang melalui keanggotaan suatu Parpol, kelompok kepentingan/penekan seperti misalnya ormas NU dan Muhammadiyah yang memiliki basis massa tradisional di Kabupaten Hulu Sungai Utara ataupun penyampaian aspirasi lewat opini publik.

Warga masyarakat diseputar Kota Amuntai yang umumnya bermatapencaharian disektor informal tidak tertarik untuk ikut terlibat dalam aktivitas politik baik dalam kepengurusan suatu parpol, kelompok kepentingan/penekan, dan opini publik. Sebaliknya bagi warga masyarakat yang berstatus PNS menyadari ketentuan bahwa netralitas PNS itu adalah suatu keharusan.

\section{Keterlibatan Dalam Penyelenggaraan Pemilu}

Pemilu yang diadakan dalam kurun waktu tertentu didalam suatu negara demokrasi menduduki peran penting bagi pelaksanaan kedaulatan rakyat secara langsung, bebas, dan rahasia. Di Indonesia pemilu dapat berbentuk pemilihan legislatif maupun eksekutif, baik ditingkat nasional, propinsi, hingga kabupaten/kota. Suatu pemilu dapat dikatakan berlangsung demokratis bilamana rakyat memberikan suaranya tanpa ada tekanan atau paksaan. 
Di Kabupaten Hulu Sungai Utara, dari pemilihan umum Bupati/Wakil Bupati tahun 2012 diketahui dari 163.655 pemilih hanya sekitar 111.743 atau $68 \%$ pemilih yang datang ke TPS memberikan hak suaranya. Jumlah ini sudah merupakan akumulasi dari suara sah sebesar 105.595 dan suara tidak sah sebesar 6.148. Bandingkan misalnya dengan pemilihan anggota DPD tahun 2014 diempat daerah pemilihan dimana pemilih yang memberikan hak suaranya sebesar 127.570 terdiri atas suara sah 97.421 dan suara tidak sah sebanyak 30.149. Tidak jauh berbeda dengan pemilihan legislatif ditingkat DPR dimana diperoleh jumlah suara pemilih hadir ke TPS sebesar 108.489, ditingkat DPRD Propinsi Kalimantan Selatan jumlah suara pemilih yang memberikan hak suara sebanyak 108.826, dan ditingkat DPRD Kabupaten Hulu Sungai Utara sejumlah 120.805 suara pemilih (Data KPUD HSU,2012 dan 2014).

Sebelum penyelenggaraan pemilu, biasanya dilakukan pencatatan daftar pemilih berdasarkan kriteria kepemilikan KTP, domisili dan lain sebagainya untuk kemudian diverifikasi sebelum akhirnya dicetak undangan dan dilakukan pemungutan suara di berbagai TPS termasuk di luar negeri bahkan di Rumah Sakit, Lembaga Pemasyarakatan dan lain-lain.

Keterlibatan warga masyarakat di Kota Amuntai dalam penyelenggaraan pemilu untuk menyalurkan hak suaranya pada umumnya sudah bagus karena mereka bersedia untuk memberikan hak suaranya kepada calon tertentu yang diyakini dapat membawa perubahan ke arah lebih baik. Seperti ditandaskan Sanit (Pito, 2006), salah satu tujuan pemilu adalah pendidikan politik bagi rakyat melalui partisipasi dalam pemilu.

Berkenaan dengan realitas menyangkut keterlibatan warga dalam kelembagaan suatu ormas/parpol dan keterlibatan mereka dalam penyelenggaraan Pemilu, diketahui partisipasi politik masyarakat Kota Amuntai secara aktif baru sebatas dalam pemungutan suara saja padahal sejatinya kehidupan politik tidak hanya bergantung pada satu aktivitas penyelenggaraan pemilu saja, karena diluar itu masih ada ruang partisipasi seperti berkecimpung dalam dunia Ormas/Parpol, melakukan kontrol terhadap kinerja eksekutif/legislatif dan lain sebagainya. Hal ini bertolakbelakang dengan maksud partisipasi politik yang dikutip Bochel (2015) sebagai upaya membangun relevansi politik dalam bingkai kewarganegaraan. Atau sebagaimana dijelaskan Crick (2015) bahwasanya melek politik sendiri menyangkut pemahaman tentang konsep-konsep, even-even, serta hak-hak politik yang berlangsung didalam kehidupan sehari-hari.

\section{Minat Politik}

Setiap makhluk hidup terlahir dengan memiliki naluri politik (zoon politicon) sebagaimana disitir Aristoteles. Dalam bahasa sederhana, politik mengajarkan kepada manusia bagaimana struggle for life pada awalnya namun pada gilirannya bisa menembus batas hingga merambah struggle for power. Tentu selalu ada kepentingan dibalik aksi politik yang dilakukan.

\section{Ketertarikan Terhadap Dunia Politik Praktis}

Persepsi masyarakat Kota Amuntai terhadap dunia politik umumnya berkisar pada keanggotaan dalam suatu parpol tertentu meski sesungguhnya keikutsertaan dalam dunia politik praktis tidak mesti terlibat dalam suatu parpol atau underbouw-nya, melainkan juga dapat melalui ormas baik berupa kelompok kepentingan/kelompok penekan atau bahkan yang lebih massif dalam bentuk opini publik.

Oleh karenanya pula, sebagian warga masyarakat menganggap dunia politik dengan penilaian yang positif. Tetapi tak bisa dipungkiri bahwa sebagian lainnya justru menilai secara apriori (negatif) terhadap aktivitas didunia politik dengan berbagai alasan yang terkesan subjektif.

\section{Ketertarikan Sebagai Peserta/Kontestan Pemilu}

Pemilu seringkali 'menggoda' banyak orang untuk ikut mencalonkan diri sebagai peserta/kontestan. Betapa tidak, bilamana terpilih maka ia akan dikelilingi dengan berbagai fasilitas selaku salah satu pejabat negara/daerah. Segala materi dan bentuk penghormatan akan tersemat didirinya sehingga menambah 
kepercayaan diri dan wibawa di depan khalayak ramai.

Diluar itu, banyak warga masyarakat Kota Amuntai yang memandang miring dengan anggapan kompetisi didunia politik itu memerlukan asupan dana yang tidak sedikit dan juga tidak mudah untuk diterabas. Dilingkungan masyarakat sudah bukan rahasia umum apabila pemberian uang atau sembako akan ramai apalagi menjelang penyelenggaraan pemilu.

Mencermati realitas menyangkut ketertarikan masyarakat Kota Amuntai terhadap dunia politik praktis secara umum dan bahkan sebagai kontestan pemilu, diketahui sebagian besar warga masyarakat memiliki kecenderungan negatif terhadap pemilu. Penilaian negatif semacam ini akan dengan mudah meruntuhkan minat politik warga masyarakat. Realitas tersebut tentunya bertolakbelakang dengan maksud Hadenius (Pito, 2006:) bahwa pemilu yang berkualitas adalah memenuhi kriteria keterbukaan, ketepatan dana, dan keefektifan pemilu. Hal ini sekaligus bertentangan dengan maksud minat politik yang dikutip Bochel (2015) terutama sebagai upaya membangun relevansi politik dalam bingkai kewarganegaraan disamping pendapat Crick (2015) yang mana melek politik adalah menyangkut pemahaman tentang konsepkonsep, even-even, serta hak-hak politik yang berlangsung didalam kehidupan sehari-hari.

\section{KESIMPULAN}

Melek politik (political literacy) memduduki peran penting dalam mengawal kualitas penyelenggaraan pemilu dinegara demokrasi. Di Kabupaten Hulu Sungai Utara terutama diseputar Kota Amuntai, pengetahuan politik warga masyarakat pada umumnya relatif rendah dimana istilah politik tidak dimaknai sebagaimana arti sesungguhnya disamping ketidakpahaman relevansi antara pemilu dan pembangunan daerah. Partisipasi politik warga masyarakat Kabupaten Hulu Sungai Utara secara umum juga dapat dikatakan masih rendah karena pada umumnya mereka yang bekerja disektor informal cenderung menghindari keterlibatan dalam aktivitas politik praktis. Dan walaupun mereka berpartisipasi aktif dalam penyelenggaraan pemilu namun mereka terkesan tidak peduli pada output pemilu yang justru lebih menentukan terhadap kesejahteraan masyarakat.

Selanjutnya, minat politik warga masyarakat Kabupaten Hulu Sungai Utara umumnya juga tergolong masih rendah karena sebagian dari mereka menilai apriori terhadap aktivitas politik praktis walaupun tak dipungkiri adapula sebagian dari mereka yang menilai positif terhadap dunia politik. Terlebih lagi dalam konteks kompetisi politik yang bagi mereka sulit diterabas dan membutuhkan asupan dana tidak sedikit.

Guna meningkatkan melek politik masyarakat Kota Amuntai Kabupaten Hulu Sungai Utara, disarankan kepada penyelenggara Pemilu di Kabupaten Hulu Sungai Utara terutama KPUD dan Panwaslu agar melakukan sosialisasi politik secara intens terhadap masyarakat luas terutama yang berada di kawasan pedesaan. Sosialisasi politik yang dimaksud sebaiknya juga menggandeng peran serta pemerintah daerah, organisasi kemasyarakatan dan juga kalangan perguruan tinggi didaerah. Partai-partai politik didaerah seyogyanya juga melakukan sosialisasi politik sebagai perwujudan salah satu fungsi partai politik terutama dikawasan-kawasan yang menjadi basis massa parpol yang bersangkutan dengan mengedepankan etika politik yang lazimnya menjadi salah satu ideologi politik partai politik.

\section{REFERENSI}

Bochel, Hugh. 2015. Political Literacy (Online), (http://www.google.com, diakses 5 Juli 2015).

Crick, Donald. 2015. Political Literacy and Citizenship. (Online), (http//:www.google.com, diakses 7 Juli 2015)

Fathurrahman, Deden. Sobari, Wawan. 2004. Pengantar Ilmu Politik. Malang: UMM.Press.

Kariada, I Made. 2015. Fenomena Melek Politik Masyarakat Klungkung Pada Pemilu 2014 dan Pemilukada 2013. Fisip 
Universitas Udayana dan KPUD Klungkung.

Surbakti, Rahlan. 1999. Memahami Ilmu Politik.Grasindo. Jakarta
Pito, Andrianus. 2006. Mengenal Teori-Teori Politik. Bandung: Nuansa. 